\title{
Gender Issues In Japan
}

\author{
Kazuyo Yamane \\ University of Kochi \\ Japan
}

\begin{abstract}
Japan ranks $8^{\text {th }}$ out of 177 countries in the Human Development Index which indicates the quality of life. However, Japan ranks $54^{\text {th }}$ out of 93 countries in the Gender empowerment Measure (GEM), which means that Japanese women's participation in politics and economy is very low. Why is there such a situation? First, it is not easy for women to have a job and do household chores at the same time because men tend to be forced to work for long hours and they do not have much time for household chores and taking care of children. There are also many men who tend to think that women are supposed to do household chores and take care of children. It is necessary to change working conditions of both men and women and also educate people about the importance of equality between men and women at school and communities as well as through media.

There are women's organizations which aim to improve the lives of women and children. It is encouraging that such women have been making great efforts to solve gender issues as well as other issues on peace, human rights, the environment and sustainable development cooperating with women in the world.

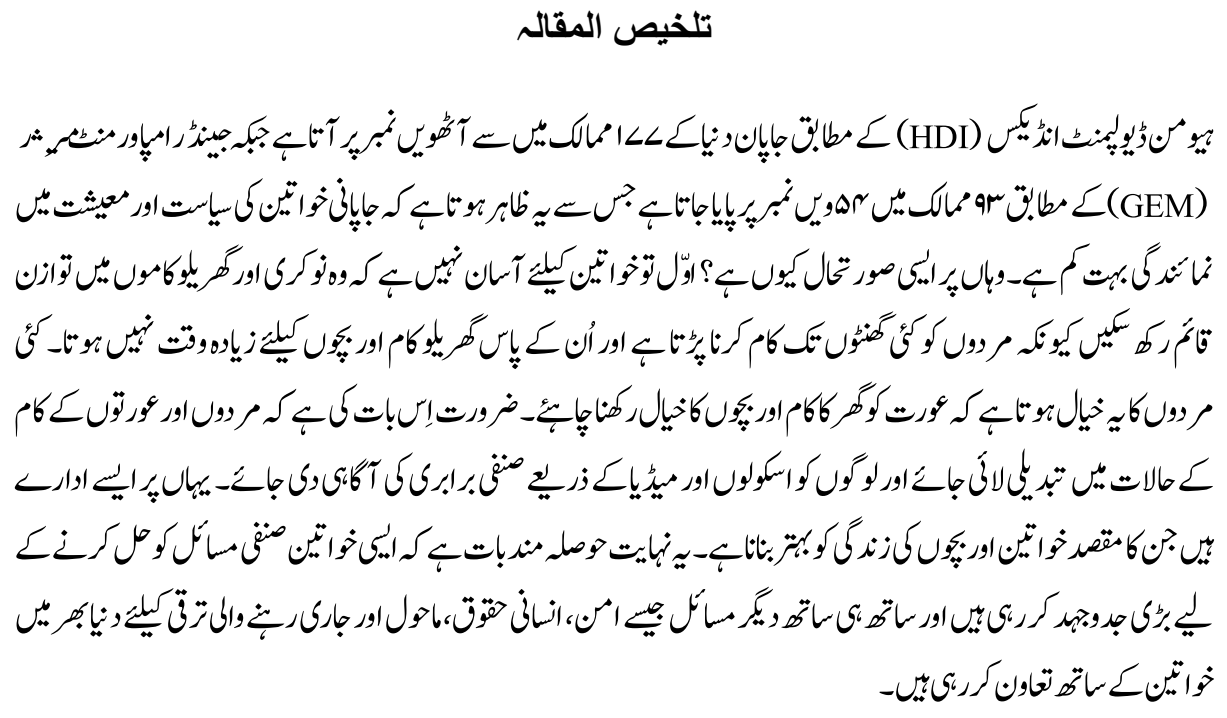

\section{Introduction}

It is said that "the gender empowerment measure (GEM) reveals whether women take active part in economic and political life? It tracks the share of seats in parliament held by women; of female legislators, senior officials and managers; and of female professional 
and technical workers- and the gender disparities in earned income, reflecting economic independence. Differing from the GDI (Gender-related Development Index), the GEM exposes inequality in opportunities in selected areas". According to Human Development Reports of the United Nations Development Programme, it is reported that Japan ranks $54^{\text {th }}$ out of 93 countries in the GEM. This means that Japanese women's social, political and economic position is relatively low.

Statistics in various fields of gender issues were published in "Women \& Men in Japan" by Research Committee of Gender Equality and Education in Research Institute of Democracy and Education in 2008. The Institute was founded in Tokyo in 1992. Gender issues in Japan will be analyzed mainly in terms of the following points based on various statistics in this article: women's participation in politics and society, labour and wages, education, work, childcare and social welfare.

\section{Japanese Women's Participation in Politics and Society}

Japan ranks $8^{\text {th }}$ out of 177 countries in the Human Development Index (HDI) which indicates the quality of life. It is impressive that Japanese women's life expectancy is the highest in the world: 86 years old, according to Nikkei Newspaper dated July $17^{\text {th }}, 2009$. However, Japan ranks $54^{\text {th }}$ out of 93 countries in the GEM. As for employers, professionals and technological experts, the disparity of the percentages among the sexes is not very high: the percentage of women in professional and technical jobs are nearly $50 \%$. But their incomes are fairly low and the percentage of females in managerial posts is below $10 \%$, according to Labour Force Survey by the Ministry of Internal Affairs and Communications (Inoue, 2009). ${ }^{1}$

The extent of their participation in policy-making is quite small. In the international comparison of the rate of female members of the national assembly, Japan ranked lowest among the developed nations in 2006. The highest percentage of female members in the national assembly (Lower House or the single chamber) in 2006 was: Sweden $(47.3 \%)$ while Japan's rate was only $9.4 \%$ according to Inter-Parliamentary Union (IPU) (Inoue, 2009). ${ }^{2}$ It is interesting that more than half of the Japanese staff of an international organization such as the WHO, ILO and IMF are women according to "Survey on Women's Participation in Policy/Decision Making" by Cabinet Office in 2005. However, female legislators account for about $13 \%$ of elected representatives to the day, which is much lower than the case in other countries as of October, 2009. This rate has been increased since 2006, but it is not enough.

As for female representatives in local assemblies, women representatives account for less than $10 \%$ of legislators in the assemblies while men are dominant, according to the Election Department of the Ministry of Internal Affairs and Communications. As for female heads of local governments, male heads account for almost $99 \%$ of local and 
regional leaders. An exception is governors of prefectures: the rate of female governors is about $10 \%$, but this is not enough to include women's voices in local policies.

Why is the rate of Japanese female participation in politics so low? First, it is not easy for women to have a job and do household chores at the same time because men tend to be forced to work for long hours and they do not have much time for doing household chores and taking care of children. There are also many men who think that women are supposed to do the above. This will be explored more in the next section.

Secondly, it seems that women are not well aware about the electorate system and are unable to contribute in policy making in the future. Heroes and leaders that are taught at school and reported in media are often men and it is difficult for women to known as leaders, pioneers and peace makers.

Thirdly, there is no quota system in Japan. In Sweden that ranks first in percentage of female members of the national assembly in 2006 (47.3\%), there is political party quota for electoral candidates. In Japan there is no such political party quota, though there are some women politicians in the ruling Democratic Party of Japan (13\%), the Social Democratic Party (28\%), and the Japan Communist Party (11\%) as of October 2009 (Mitsui). The average rate of women politicians in political parties after the general election of the House of Representatives in August 2009 is $11.3 \%$, which is highest in Japan, but it is still very low in the world. The average rate of female members of the national assembly is $18.5 \%$ in the world and Japan ranks 119 in 187 countries according to statistics of the Inter-Parliamentary Union. Today, quota system aims at ensuring that women constitute at least a "critical minority" of 20, 30 or 40 percent, or even to ensure true gender balance of 50-50\% (The website of Global Database of Quotas for Women). It seems that Japan needs such quota system.

Fourthly, finance is required to participate in elections and it is not easy for women to run in an election unless she belongs to a political party. There are other reasons for low participation due to the fact that Japanese women's social, political and economic position is relatively low.

\section{Present Situation of Japanese Women}

The rate of working women aged between $25-54$ years is $67.4 \%$, which ranks $24^{\text {th }}$ in Organization for Economic Cooperation and Development (OECD) countries, according to OECD Employment Outlook (OECD 2008, Paris). On the other hand, educational background of Japanese women aged 25-54 years ranks 3rd following Finland and Canada. Japanese women's rate of higher education is $42.5 \%$ while the average rate of the OECD countries is $28.5 \%$. This shows that it is necessary to take measures to give more chances to well-educated women in Japan. The reason why the rate of working 
women is lower than men is that there aren't enough nursery schools for working mothers. There is also sexual discrimination against women: it is not easy for women to continue work after they give birth to a baby. Furthermore, women tend to think that they should stay home once they give birth to a baby and take care of children.

How many hours do Japanese women spend in doing household chores? The longest time in Japan is 5 hours 33 minutes in Kanagawa Prefecture while the shortest one is 4.2 hours in Kochi Prefecture according to Owarai Gender-ron (Sechiyama,2001) ${ }^{3}$. The reason is that more women tend to work in Kochi than those in other prefectures because there is no big industry and men's average wages are relatively low and women have to work to make ends meet. There is also historical background that Kochi is the birthplace of the movement for freedom and human rights in Japan. Kusunose Kita (1836-1920) the first woman who demanded woman suffrage in Japan and achieved it in Kamimachi town in Kochi. It was much earlier in Japan as compared to other countries because it was 1893 when woman suffrage was achieved in New Zealand at national level. Kita Kusunose was influenced by the democratic movement in Kochi. After her husband passed away, she tried to vote, but it was rejected because a woman did not had a right to vote. However, she demanded her right to vote because she paid tax. She wrote a letter to the prefectural office asking if there should be any discrimination against women in terms of human rights. She won and women's suffrage was granted in Kochi in 1880.

Women in Kochi seem to be very independent and hard working, which may be due to long tradition of the movement for democracy. Kochi is said to be "the Kingdom of Nursery School" because there are so many nursery schools. This is because women have been working hard and they need it in order to keep working after giving birth to a baby. There was a women's movement to create nursery schools as many as mail-posts in Kochi. However, it is unfortunate that the rate of divorce is pretty high in Kochi in comparison with other prefectures: Kochi ranks $8^{\text {th }}$ among 47 prefectures in Japan in the rate of divorce that is $2.13 \%$ while Okinawa ranks $1^{\text {st }}(2.71 \%)$ according to Tokyo Newspaper dated May 10, 2009.

Japanese women spent 32 hours per week for household chores while it was three hours and a half for men as of 1990 (Sechiyama,2001) ${ }^{4}$. This means that women do house hold chores 4 hours and half a day while men spend only 31 minutes a day. This is very different in comparison with Finland where women spend 25 hours a week on doing household chores while men spend 13 hours and a half as of 1987. This means that Finnish women spend 3 hours and half a day while men spend about two hours a day.

Current data shows that Japanese women spend twice as much time as women in the USA, England, China and Sweden on household chores as of June in 2009, according to Yomiuri Newspaper dated September $1^{\text {st }}$. A questionnaire was sent to women from their age group of 20s to 50s: 1000 women in Japan and 300 women in the USA, England, 
China and Sweden by P\&G Company in Kobe City, Japan. The average time for chores is 4 hours 24 minutes in Japan while it was one hour and 54 minutes in China, 2 hours and 24 minutes in the USA. This means that women in China and the USA spend about half time of Japanese women on chores. More than half of Japanese women cook and wash dishes more than three times a day, but women in the other countries do so once or twice a day. As a result, about $60 \%$ of Japanese women are not satisfied with the balance between time for household chores and their own time while more than half of women in the other countries are satisfied with having their own time. The latest data shows the time that Japanese women spend on chores has not changed since 1990.

Many women leave regular employment for child birth and taking care of their parents or in-laws. This is because the Japanese government has not spent enough money for nursery schools and nursing homes while a lot of money was spent on armament and US military bases in Japan: the budget for welfare has been relatively low. Comparing proportion of social welfare budget to GDP, the rate of Japan was below average of OECD countries: it was $17.7 \%$ while the average rate of the OECD countries was $20.7 \%$ according to "Social Expenditure Database: Aggregated Data 2007" by OECD (Inoue, 2009). ${ }^{5}$ The highest rate was $31.3 \%$ in Sweden. On the other hand, over $\$ 46$ billion is used for armament (the 7th highest in the world according to the SIPRI: Stockholm International Peace Research Institute) in 2008 (Kochi Newspaper,2009) as well as 280 billion yen a year has been used for US military bases in Japan. When women return to work, they are often forced to accept part time or temporary works, which means that their wages are much lower than men's wages.

Income of the female workers is about $66.8 \%$ of that of male workers in Japan in 2007 (Kochi Newspaper,2009). ${ }^{6}$ As for composition of female workers by employment status, the rate of regular female workers was $46.5 \%$ and the rate of female part-time workers was $33.1 \%$ in 2007 . The rate of temporary workers was $7.6 \%$ and that of female workers in other employment was $12.8 \%$ according to "Report on Japanese Women 2008" by Federation of Japanese Women's organizations (Kochi Newspaper,2009) ${ }^{7}$. This means that the rate of regular workers is less than half of all the female workers and more than half of part-time female workers.

It is not easy for full-time female workers to work, do reproductive along with the productive, while their husbands work until late at night. As for part-time female workers, they suffer from the lack of income to make ends meet because the budget for welfare has been reduced by 220 billion yen every year since 2001. This means, the increase in the cost for medicine and nursing care and women, especially single mothers, have been having hard time to live. For example, mother of three children aged 30 was fired by Canon Company against a contract and her children were taken care, of at day care center's. She had been looking for a job, but it was hard for her to get one. This story was told by her at Mothers' Congress held on July $25^{\text {th }}$ and $26^{\text {th }}$ in Kyoto and 
shared with other participants. Some of them sniveled listening to her story that she would like to live with her children and get a job.

Japanese women also suffer from domestic violence at home: almost one out of three married women is a victim of domestic violence. According to the survey on violence between men and women done by the Cabinet Office in 2008 (Shinfujin Newspaper, 2009). $13.3 \%$ of such women answered that they felt their lives were in danger. As for women in their teens and $20 \mathrm{~s}, 13.6 \%$ of them answered that they suffered from violence by their boyfriends. $48.4 \%$ of them answered that they suffered physically and mentally. $21.9 \%$ of them answered that they were living an in-secured life. As a result of domestic violence, $13.3 \%$ of women quit or changed their jobs.

These examples indicates that, Japanese women have faced various problems. Then what have they done to solve such problems?

\section{Efforts to Change Reality by Women at Grassroot Level}

There are various women's NGOs in Japan and some of them will be introduced to show how they have addressed gender issues.

Japan Federation of Women's Organizations (Nihon Fujin Dantai Rengokai) was founded on $5^{\text {th }}$ April in 1953 during the Korean War. The purpose was to unite women from all over Japan for promoting peace. United actions were organized to solve women's issues hoping for peace, democracy, gender equality, happiness for children and the improvement of education and welfare.

The federation has been active nationally as well as internationally. It became a member of Women International Democratic Federation in 1957 and contributed to the development of the federation. In the 1970s the Japan Federation collected a donation of 100 million yen to build a health center for mothers and children in Vietnam cooperating with women of the world. They have been promoting solidarity with women globally to improve Japanese women's social position (Address of Japan Federation of Women's Organizations).

One of the organizations that belong to the Japan Federation of Women's Organizations is the New Japan Women's Association. It was founded in 1962 and joined hands with women of the world for building peace. It has its branches in all the forty-seven prefectures and in 880 municipalities according to its website (The website of Schinfujin).

The New Japan Women's Association (NJWA or Shinfujin) was founded on October 19, 1962 at the call of 32 women including Raicho Hiratsuka (a pioneer of the Japanese women's movement and the first president of the Japan Federation of Women's 
Organizations), Yaeko Nogami (a writer) and Chihiro Iwasaki (an artist of paintings for children.) Their activities are carried out in over 10,000 groups, which are organized all over the country; in workplaces and communities, including rural areas. The association has a head office that unites chapters working in all the 47 prefectures and branches in 880 municipalities. Under the five objectives, members of the association work to realize all women's demands concerning issues of women's rights, as equality with men, better working and living conditions, measures to support child-care, education, environmental protection, peace and abolition of nuclear weapons.

The five objectives are:

1. Protect the lives of women and children from the danger of nuclear war.

2. Oppose the adverse revision of the Constitution and the resurgence of militarism.

3. Work together for better living conditions, women's rights and children's wellbeing.

4. Win genuine national independence, democracy and emancipation of women.

5. Join hands with women in the world for building lasting peace.

The association is opened to all women who agree with the above five objectives, irrespective of their thought, creed or political background. It publishes a weekly newspaper called "Shinfujin Shinbun" with 300,000 readers, and a monthly magazine "Josei \& Undo" ("Women \& Movement"). It is a member of the Japan Federation of Women's Organizations (Fudanren) as mentioned above and the International Women's Year Liaison Group (comprising 40 major Japanese women's organizations.) In May 2003, the association was granted Special Consultative Status by the U.N. Economic and Social Council.

The association held its $23 \mathrm{rd}$ National Convention in Chiba on November $10^{\text {th }}$ and $11^{\text {th }}$ 2007 (The National Convention held biannually.) About 980 delegates from all over the country attended the Convention to share their experiences of various activities.

The Convention adopted a resolution that put forward the association's action plan for the coming two years, entitled "No to Poverty, Disparities and War! Defend Article 9 of the Japanese Constitution! At this Time of a Dramatic Change, Let us Make Shinfujin Bigger and Stronger." It also adopted a special resolution calling for a united effort of women to scrap the new anti-terrorism special measures bill whose aim was to enable Japan's Self Defense Forces to support war abroad.

For example, there is a danger of changing the Japanese Constitution, especially Article 9 that renounces war and military force. 1063,051 signatures against the revision of the Constitution were collected in two years. 511,094 signatures were collected to demand the abolition of nuclear weapons. It became possible in various parts of Japan that 
medical cost became free until children become 15 years old because of women's activities.

There is also a mother's movement for promoting sexual equality and peace. The first Mother's Congress was held in June 1955 in the course of the development of the movement against Atomic \& Hydrogen bombs that followed the tragedy at Bikini Atoll in which a Japanese tuna fishing boat was showered with fallout from a U.S. hydrogen bomb test explosion on $1^{\text {st }}$ March, 1954. Japanese mothers expressed their strong desire to protect children against nuclear war in the first Mothers' Congress. The annual Japan Mother's Congress, which has represented Japanese mother's wishes for peace, held at various places in Japan.

The $55^{\text {th }}$ Conference of Mother's Congress was held in Kyoto on July $25^{\text {th }}$ and $26^{\text {th }}$ and a total of 17,500 people participated in it (Zenkoku Shoukou Shinbun, 2009). There have been various issues such as disparity in income, degrading welfare and environmental problems. Mothers gathered to change such a situation so that people would be able to live in peace and harmony. They exchanged ideas and experiences to improve their lives.

For example, an illustrator said, "I am paid only 358 yen an hour and my pride is trampled. I hope that such a system will be abolished as soon as possible and women will be able to live more humanly." (The average minimum wage is 713 yen) (Yomiuri Online Newspaper).

Many workers are forced to work for long hours every day. Mrs. Hiroko Uchino lost her husband who used to worked for Toyota Motor Company, he worked over 144 hours after his regular work per month (Shinfujin Newspaper, 2008). This means that he worked about 13 hours a day including weekends. He is not exceptional: so many workers are forced to work after their regular work for free and they didn't get much time to sleep. She filed a lawsuit and won the case after six years. Japan tends to be regarded as a rich country, but workers and women are not rich at all. However, it is encouraging that women are not quiet anymore and speak out more than before to improve their lives. Mother's Congress is also held locally in various parts of Japan and gender issues have been discussed between representatives of mothers and local government as well as Japanese government. There is such a slogan as "Let's get rid of lonely mothers" so that mothers become friends to solve gender issues and problems surrounding their children.

\section{Conclusion}

Japan ranks $8^{\text {th }}$ out of 177 countries in the Human Development Index (HDI) which indicates the quality of life of people. It is great that Japanese women's life expectancy is the longest in the world. However, Japan ranks $54^{\text {th }}$ out of 93 countries in the GEM, which means that Japanese women's participation in politics and in economy is very low. 
Why is there such a situation? First, it is not easy for women to have a job and do house hold chores at the same time because men tend to be forced to work for long hours and they do not have much time for doing household chores and taking care of children. There are also many men who tend to think that women are supposed to do household chores and take care of children. It is necessary to change working conditions of both men and women and also educate people, especially children about the importance of equality between men and women at school and communities as well as through media.

There are women's organizations which aim to improve lives of women and children such as Japan Federation of Women's Organizations and the New Japan Women's Association. It is encouraging that such women have been making great efforts to solve gender issues as well as other issues on peace, human rights, environment and sustainable development cooperating with women in other countries in the world.

\section{End Notes}

${ }^{1}$ Inoue, Yumiko (2009) Women \& Men in Japan, Research Institute of Democracy and Education. p. 2, 5, 44.

${ }^{2}$ Ibid., p. 2.

${ }^{3}$ Sechiyama, Kaku (2001) Owarai Gender-ron (Gender Theory for Laugh), Keiso Shobo. p. 23.

${ }^{4}$ Ibid., p. 19 (The data is from based on a research in 1995 by NHK broadcasting company).

${ }^{5}$ Inoue, op. cit, (2009) p. 44.

${ }^{6}$ Kochi Newspaper (June $\left.9^{\text {th }}, 2009\right)$ Chinese expenditure for Armament is 2 nd in the World, p. 18.

${ }^{7}$ Ibid., p. 14

\section{References}

Address of Japan Federation of Women's Organizations (Nihon Fujin Dantai Rengokai)Address: 4-11-9-303 Sndagaya, Shibuya-ku, Tokyo, Japan 151-0051 Website: http://www16.ocn.ne.jp/ fudanren/email:fudanren@cocoa.ocn.ne.jp

Kochi Newspaper (June $\left.9^{\text {th }}, 2009\right)$ Chinese Expenditure for Armament is 2 nd in the World. 
Mitsui, Mariko "The number of women winners of the general election of the House of Representatives is the highest in history, but the female rate is the lowest in the world" In Japan Alternative News for Justices and New Cultures (in Japanese) Retrieved on September 2nd 2009.

http://www.news.janjan.jp/government/0909/0909019596/1.php

OECD (2008, Paris) Outlook of Employment http://docs.google.com/gview? $\mathrm{a}=\mathrm{v} \& \mathrm{q}=$ cache:Csn9V11YhAEJ: www.oecdtokyo2.org/pdf/theme pdf/employment pdf/20080701employment jap an.pdf + oecd+employment + outlook $+2008 \& \mathrm{hl}=\mathrm{ja} \& \mathrm{gl}=\mathrm{jp} \& \operatorname{sig}=\mathrm{AFQjCNHej8mkR}$ hKeeuYsZcQfrEHVNuPD7Q (in Japanese)

Shinfujin Newspaper (August 7th 2008), http://www.shinfujin.gr.jp/a 1 shinbun/ kiji08/ $200808 \quad 7$ hahaoyataikai.html

Shinfujin Newspaper (April $\left.9^{\text {th }}, 2009\right)$ One out of three women is a victim of DVD.

The website of Global Database of Quotas for Women a joint project of IDEA (International Institute for Democracy and Electoral Assistance) and Stockholm University. http://www.quotaproject.org/aboutQuotas.cfm

The website of Shinfujin: http://www.shinfujin.gr.jp/eng/1_what/index.html Address: 510-20, Koishikawa, Bunkyo-ku, Tokyo 112-0002, Tel: 81-3-3814-9141 Fax: 813-3814-9441, E-mail: s-intl@shinfujin.gr.jp

Yomiuri Online Newspaper (September 2 $2^{\text {nd }}$ ) http://www.yomiuri.co.jp/ atmoney/ enterprises/jinji/20090902-OYT8T00498.htm

Zenkoku Shoukou Shinbun (National Commerce Newspaper) (August 10 ${ }^{\text {th }}, 2009$ ). http://www.zenshoren.or.jp/shoukai/fujin/090810-08/090810.html

Kazuyo Yamane is a Co-operative Lecturer in Peace studies, Global issues, English, Kochi University, Kochi, Japan. 